NBER WORKING PAPER SERIES

\title{
THE COSTS OF PRICE STABILITY - DOWNWARD NOMINAL WAGE RIGIDITY IN EUROPE
}

\author{
Steinar Holden \\ Working Paper 8865 \\ http://www.nber.org/papers/w8865 \\ NATIONAL BUREAU OF ECONOMIC RESEARCH \\ 1050 Massachusetts Avenue \\ Cambridge, MA 02138 \\ April 2002
}

Previous versions of the paper have circulated under the title "Monetary policy and nominal rigidities under low inflation". I am grateful John Driscoll, Daniel Gros, Hans Haller, Kalle Moene, Asbjørn Rødseth, Stein Evju, as well as participants at presentations at CESifo, Harvard University,Virginia Polytechnic and State University, the EEA meeting in Lausanne, University of Essex, Oxford University, and the Geilo seminar for useful comments on earlier drafts, to Larry Katz and Greg Mankiw for helpful discussions, and to the NBER for the hospitality when main parts of this paper was written. The views expressed herein are those of the author and not necessarily those of the National Bureau of Economic Research.

(C) 2002 by Steinar Holden. All rights reserved. Short sections of text, not to exceed two paragraphs, may be quoted without explicit permission provided that full credit, including $\mathbb{C}$ notice, is given to the source. 
The Costs of Price Stability - Downward Nominal Wage Rigidity in Europe

Steinar Holden

NBER Working Paper No. 8865

April 2002

JEL No. J5, J6, E31, E52, K31

\begin{abstract}
In most European countries, the prevailing terms of employment, including the nominal wage, can only be changed by mutual consent. I show that this feature implies that workers have a strategic advantage in the wage negotiations when they try to prevent a cut in nominal wages. If inflation is so low that some nominal wages have to be cut, the strategic advantage of the workers' induces higher unemployment in equilibrium. The upshot is a long run tradeoff between inflation and unemployment for low levels of inflation. The prediction that low inflation involves higher unemployment in Europe but not in the US, is consistent with previous empirical findings.
\end{abstract}

\author{
Steinar Holden \\ Department of Economics \\ University of Oslo \\ Box 1095 Blindern, 0317 \\ Oslo, Norway \\ steinar.holden@econ.uio.no \\ http://folk.uio.no/sholden/
}




\section{$1 \quad$ Introduction}

In recent years, a number of countries have adopted explicit inflation targets for monetary policy, reflecting a general agreement that monetary policy must ensure low inflation. Yet several economists have argued that if policy aims at too low inflation, downward rigidity of nominal wages may lead to higher wage pressure, involving higher equilibrium unemployment (eg Tobin, 1972, Holden, 1994, and Akerlof, Dickens and Perry, 1996, 2000). ${ }^{1}$ This latter view has been strengthened by the increasing body of evidence documenting downward nominal wage rigidity in many OECD countries (see references in section 7). However, against this view, sceptics have argued that any downward rigidity that may exist is the result of an inflationary environment, and that society will adapt to a zero inflation policy without large and persistent impact on output and employment (Ball and Mankiw, 1994, Gordon, 1996).

A problem when evaluating these two opposing views is that there is no generally accepted explanation for why nominal wages may be rigid downwards. In this paper I argue that the institutional framework of the wage setting crucially affects the existence and importance of downward nominal wage rigidity. More specifically, I argue that the extent of downward nominal wage rigidity, and the unemployment costs associated with very low inflation that this involves, are related to three key factors: the coverage of collective agreements, the legal framework at renegotiations of collective agreements, and the strictness of the employment protection legislation for non-union workers. The key underlying idea is that employment contracts typically have a fixed nominal wage

\footnotetext{
${ }^{1}$ Low inflation may also limit the scope for expansionary monetary policy as the nominal interest rate cannot be negative, cf Keynes (1936).
} 
that is renegotiable only by mutual consent (MacLeod and Malcomson, 1993, Holden, 1994). In many cases the practical importance of this legal requirement is negligible. For example, in the US labour market the standard presumption is that employment is at-will, the legal interpretation in effect being that the employer unilaterally can cut nominal wages (Malcomson, 1997). However, in other countries, and in particular in collective wage setting, the legal requirement of mutual consent is more important. I show that this requirement implies that workers/unions have a strategic advantage in the wage setting when they try to prevent a nominal wage cut. If inflation is so low that employers want to cut nominal wages, this strategic advantage leads to stronger wage pressure and higher unemployment in equilibrium. The upshot is the existence of a long run tradeoff between unemployment and inflation.

The basic theoretical framework draws heavily on Holden (1994), but extending the analysis in several ways. Most importantly, I include a non-union sector, allowing for an investigation of the causes of nominal wage rigidity outside the union sector, as well as for comparisons between countries with different degrees of unionisation. Furthermore, I explore the model numerically, in an extended version allowing for productivity growth, changes in relative wages and non-strike industrial action.

Other recent explanations of downward nominal wage rigidity have generally appealed to money illusion or fairness considerations, ie that workers view a cut in nominal wages as unfair. I do not wish to contend the existence of such effects (cf documentation in eg Shafir, Diamond and Tversky, 1997, and Bewley, 1999). Rather, I think that fairness considerations and legal effects may re-enforce each other. However, understanding the reasons for downward nominal wage rigidity seems crucial in 
evaluating their effects and assessing to what extent rigidities may disappear in a zero inflation economy.

The idea of the present paper is very different from the literature on overlapping wage contracts of Taylor (1979), both when it comes to theoretical explanation and empirical implications. In the present model, persistent nominal rigidity linking consecutive contract periods is explained without staggering of wage contracts. Furthermore, the long-run Phillips curve has downward-sloping parts, in contrast to the vertical long run Phillips curve in the overlapping contracts literature.

The argument of the paper has important implications for the inflation target that monetary policy should aim at. In countries with high bargaining coverage and regulated labour markets, aiming at very low inflation may involve considerable costs in the form of higher unemployment and reduced output. In contrast, in countries with low bargaining coverage and weak employment protection legislation, aiming at low inflation is likely to have a much smaller impact on unemployment. This contention is consistent with the empirical findings of Bullard and Keating (1995) for the period 1960-90. They find that a negative and significant long-run response of output to a reduction in inflation in European countries with low inflation (Germany, Austria, Finland and the UK), but they do not find a similar relationship in the US. Note, however, that I do not aim at finding the optimal rate of inflation - inflation clearly also involves important costs, associated with among other things increased uncertainty, reduced money holdings and capital taxation, all of which are neglected in the present paper (see eg Feldstein, 1997).

The remainder of the paper is organised as follows. In section 2, I present important institutional features of the wage setting in Western Europe and the US. The 
basic model is provided in sections 3 and 4 . Section 5 derives the equilibrium of the model. Numerical simulations are presented in section 6. In section 7, I discuss available empirical evidence. Section 8 concludes. All proofs are in the appendix.

\section{$2 \quad$ Nominal rigidity in the wage setting process ${ }^{2}$}

The crucial assumption in the model, and the source of the nominal rigidity, is that the nominal wage of the old contract affects the parties' disagreement point in the wage bargaining. This section substantiates this assumption by describing the relevant aspects of the wage setting systems in many Western European countries and the US.

Most workers in Europe are hired in permanent jobs. The general principle is then that the prevailing terms of employment are interpreted as a legal contract, and may as such only be changed by mutual consent. To reduce wages, the employer must persuade the employee to accept the wage cut. One possibility is to threaten to lay off the employee temporarily or permanently unless he accepts a wage cut. In principle, the employer can terminate the employment contract and offer a new contract with lower pay. However, in some countries, courts may interpret a job offer at lower pay as evidence that the initial dismissal was unwarranted, unless the wage reduction could be justified by the economic situation of the firm. In countries with weak employment protection legislation, like the UK, enforcing a cut in nominal wages is likely to be more feasible than in countries with stricter employment protection legislation, like Germany, Italy and Sweden.

\footnotetext{
${ }^{2}$ This section draws upon the country chapters in Blanpain (1994) and private communications with Stein Evju.
} 
For workers covered by collective agreements, ie the large majority of employees in Western Europe, ${ }^{3}$ additional issues arise. The wage regulations in collective agreements are usually of finite duration. However, when this period has expired, the employer may nevertheless not lawfully unilaterally change the terms of the agreement. Unless a work stoppage has been initiated, it is in most countries a well established practice that production continues under the terms of the old agreement until a new agreement is reached, even after the old agreement has expired (holdout).

Again, the employer has a variety of measures that can be used to persuade or threaten unions/workers to accept a nominal wage cut. Workers can be laid off temporarily or permanently, possibly in connection with a plant closure, or the firm can use lock-out. Alternatively, the employer can unilaterally terminate the collective agreement, following specific, often time-consuming, legal procedures. However, this may involve costs, as the agreement also regulates work. Furthermore, in many countries the terms of the agreement are in this event considered to be included in the individual employment contracts. Thus, a wage cut still requires consent by the employees.

In many cases, the remuneration also consists of more "flexible" parts, like bonus schemes and fringe benefits. This may give the employer some scope for reducing pay even within the existing contract. I address this issue in the formal model. For now, observe that while annual fluctuations in the factors that these forms of remuneration depend on may lead to annual fluctuations in pay, there may still be contractual and labour regulations that severely restrict employers' scope of reducing remuneration at

\footnotetext{
${ }^{3}$ In most Western European countries, bargaining coverage in the market sector is about 70-80 percent, with Denmark (52), Switzerland (50), UK (35) and Ireland as notable exceptions, see (Calmfors et al, 2001) table 4.4.
} 
will. Lebow, Saks and Wilson (2000) show that US firms are able to circumvent some, but not all the wage rigidity by varying benefits.

In the US, there are much less restrictions on employers' possibility of unilaterally cutting the wage. For individual workers, the basic presumption is that employment is at will, implying that either party may terminate the employment relationship for any reason, or for no reason at all. Furthermore, if the employer announces a wage cut, the employee's continuance in service is considered to constitute acceptance, in contrast to the situation in Europe (Malcomson, 1997). However, in parts of the labour market, contracts or specific circumstances may prevent employment-atwill, making it more difficult for the employer to cut wages.

The institutional feature that prevents employers from unilaterally cutting nominal wages can be seen as a consequence of standard contract law, which generally holds that a contract between two parties can only be changed by mutual consent. This feature may play an important role in inducing efficient levels of investment, by preventing one player from reaping the return of the investment of the other by demanding a renegotiation of the contract (MacLeod and Malcomson, 1993, and Holden,1999).

\section{$3 \quad$ The model}

We consider a standard monopolistic competition economy, consisting of a large number K symmetric firms, each producing a different good (alternatively, firms may be thought of as industries, each consisting of several firms that produce an identical product under Bertrand competition). A share $\gamma$ of the economy is unionised, with one union in each firm, each with $1 / \mathrm{K}$ members. In these firms, the wage is set in a bargain between union 
and firm. The remaining share $1-\gamma$ is non-unionised, and the wage is set in an individual bargain between the worker and the firm.

The model considers one contract period; however, there is a nominal wage contract from the previous contract period, $\mathrm{W}^{\mathrm{U}}{ }_{-1}$ in all unionised firms, and $\mathrm{W}^{\mathrm{N}}{ }_{-1}$ in nonunionised firms, consistent with the large empirical prevalence of nominal contracts (see Gottfries, 1992, for a possible explanation). Note that this does not rule out indexation at specific dates: For example, at the expiration of a two-year contract, the wage is given in nominal terms even if there has been indexation after one year of the contract.

For modelling purposes related to the wage setting, the contract period is divided into an infinite number of short time spans. In each such time span, a small fraction s of the labour force leaves the work force ("retires"), and is replaced by identical workers entering as unemployed.

At the immediate beginning of the contract period, the following events take place. First, the central bank $\mathrm{CB}$ sets the total money stock $\mathrm{M}>0$. Second, wages are set simultaneously in each firm. Third, each firm sets the price and employment levels. All agents are fully aware of how the economy works, so they can predict what other agents will do at the same and later stages of the model. As agents are small, they treat the aggregate variables as exogenous.

Observe that in contrast to the literature on overlapping nominal contracts, wage and subsequently price setting are simultaneous in each firm, with perfect knowledge about the monetary policy. Thus, the effects of monetary policy in equilibrium should be interpreted as long run effects that are not based on expectational errors. 
Each firm $j$ has a constant returns to scale production function $Y_{j}=N_{j}$, where $Y_{j}$ is output and $\mathrm{N}_{\mathrm{j}}$ is employment. In principle, $\mathrm{Y}_{\mathrm{j}}$ and $\mathrm{N}_{\mathrm{j}}$ (as well as the other flow variables) may vary from time span to time span, however, in equilibrium they will be constant, and for notational simplicity I do not index time span. The real profits of the firm are

(1) $\quad \Pi_{\mathrm{j}}=\left(\mathrm{P}_{\mathrm{j}} \mathrm{Y}_{\mathrm{j}}-\mathrm{W}_{\mathrm{j}} \mathrm{N}_{\mathrm{j}}\right) / \mathrm{P}$,

where $P_{j}$ is the price of output, $W_{j}$ is the nominal wage in firm $j$, and

$$
P=\left(\frac{1}{K} \sum_{j} P_{j}^{1-\eta}\right)^{\frac{1}{1-\eta}} \quad \eta>1,
$$

is the aggregate price level. The demand function facing each firm is

$$
Y_{j}=\left(\frac{P_{j}}{P}\right)^{-\eta} \frac{M}{P} \frac{1}{K} \quad \eta>1,{ }^{4}
$$

The union cares about employment and the pay relative to workers' alternative income:

$$
\mathrm{U}_{\mathrm{j}}=\left(\mathrm{W}_{\mathrm{j}} / \mathrm{P}-\mathrm{R}\right)^{\varphi} \mathrm{N}_{\mathrm{j}}^{1-\varphi} \quad 0<\varphi<1,
$$

where $\mathrm{W}_{\mathrm{j}} / \mathrm{P}$ is the real wage, $\mathrm{R}$ is workers' alternative income and the parameter $\varphi$ measures unions' concern for employment relative to income. The alternative income $\mathrm{R}$ is

\footnotetext{
${ }^{4}$ As is well known, (3) can be derived in an optimising framework of Dixit-Stiglitz type, with households with CES utility functions defined over consumption and holdings of real money stock, where $\eta$ is a parameter in the utility function.
} 
based on the assumption that workers not hired in this firm will initially be unemployed, with payoff $\mathrm{B}>0$ (the value of leisure or non-market income), but they have the opportunity of finding a new job as new hirings occur to replace the "retirees", at an expected wage equal to the average real wage of the economy; specifically,

$$
\begin{aligned}
& \text { (5) } R=R\left(u, \frac{W}{P}\right) \equiv(1-\sigma(u)) \frac{W}{P}+\sigma(u) B \quad u<\sigma(u)<1, \quad \sigma^{\prime}(u)>0, \\
& \text { (6) } W=\left(\frac{1}{K} \sum_{j} W_{j}^{1-\eta}\right)^{\frac{1}{1-\eta}}
\end{aligned}
$$

where the aggregate rate of unemployment $\mathrm{u} \equiv 1-\mathrm{N}$ (total labour supply is normalized to unity, and $\mathrm{N}=\Sigma_{\mathrm{j}} \mathrm{N}_{\mathrm{j}}$ is aggregate employment). The function $\sigma$ captures in a crude fashion that the probability of obtaining a new job is increasing in, and lower than, the aggregate employment rate (see Layard et al, 1991, page 101 for a more detailed discussion). The specific functional forms (1)-(6) are chosen for tractability and notational simplicity but not important for the qualitative results.

Equilibrium in this model is a situation where, for given values of $\mathrm{M}$ and $\mathrm{W}_{-1}^{\mathrm{U}}$ and $\mathrm{W}^{\mathrm{N}}{ }_{-1}$, there is Nash equilibrium in prices in stage 3 , and wages are given by a subgame perfect equilibrium SPE in the wage setting in stage 2 . To find the equilibrium, we start by analysing stage 3 . The first order condition of the profit maximization problem is
(7) $\quad P_{j}=v W_{j}$,
where $v=\eta /(\eta-1)>1$. 
As profits are concave in $P_{j}$, the first-order condition (7) is sufficient to ensure a unique maximum, constituting Nash equilibrium in the price setting game. Substituting out, we obtain the labour demand, as well as the indirect payoff functions of the unions and firms

$$
\begin{aligned}
& \mathrm{N}_{\mathrm{j}}=\left(v \mathrm{~W}_{\mathrm{j}} / \mathrm{P}\right)^{-\eta}(\mathrm{M} / \mathrm{P}) / \mathrm{K} \\
& \Pi_{\mathrm{j}}=\Pi\left(\mathrm{W}_{\mathrm{j}} / \mathrm{P}, \mathrm{M} / \mathrm{P}\right)=(v-1)\left(\mathrm{W}_{\mathrm{j}} / \mathrm{P}\right)^{1-\eta} v^{-\eta}(\mathrm{M} / \mathrm{P}) / \mathrm{K}, \\
& \mathrm{U}_{\mathrm{j}}=\mathrm{U}\left(\mathrm{W}_{\mathrm{j}} / \mathrm{P}, \mathrm{R}, \mathrm{M} / \mathrm{P}\right)=\left(\mathrm{W}_{\mathrm{j}} / \mathrm{P}-\mathrm{R}\right)^{\varphi}\left(\mathrm{W}_{\mathrm{j}} / \mathrm{P}\right)^{-\eta(1-\varphi)}\left(v^{-\eta}(\mathrm{M} / \mathrm{P}) / \mathrm{K}\right)^{(1-\varphi)} .
\end{aligned}
$$

\section{$4 \quad$ The wage setting}

We first consider wage setting in the unionised part of the economy. The standard approach in models of union bargaining, eg Layard, Nickell and Jackman (1991), is to employ the Nash bargaining solution, where the disagreement points are specified as players' payoffs during a strike. Under this assumption, the wage of the old nominal contract is irrelevant, as it does not affect the strike payoffs. However, specifying the disagreement points as players' utility during a strike is a valid assumption only if a strike is an automatic consequence of a delay in reaching an agreement in the bargaining. This is clearly not the case; there is no strike unless the union initiates it. In many countries it happens frequently that the old contract expires before a new agreement is reached, and without a strike being initiated (see evidence in Cramton and Tracy, 1992, and van Ours and van de Wijngaert, 1992). In this case production continues under the terms of the old contract while the parties are bargaining (holdout). To allow for holdouts, and endogenising the strike and lockout decisions, I adopt an extension of the Rubinstein (1982) model similar to Holden (1994,1999), cf Figure 1.

The first two steps of the bargaining game, which take place in negligible time, 
determine which type of dispute (strike, lockout or holdout) prevails in the bargaining. At the third step, a standard Rubinstein bargaining game starts, where players alternate in making offers, one offer per time span. In each of the first two steps, one of the players makes an offer, which the opponent may accept (thus ending the bargaining) or reject. Upon a rejection, the rejecting player may decide whether to initiate a work stoppage. As a convention, players do not initiate a work stoppage if they can get the same payoff under the existing contract.

If a work stoppage (ie strike or lock-out) has been initiated in step one or two, both parties receive (for simplicity) zero payoffs from step 3 on, until a new agreement is reached. A key assumption is that if a work stoppage takes place, it always involves nonnegligible costs to the parties (fixed costs; Holden, 1994). These costs may be given several different interpretations. In the UK, where unions are required to keep a ballot, the costs of arranging the ballot would be part of such costs. These costs may also arise if there is a minimum time before work can be resumed after a work stoppage. Furthermore, if the model is extended to allow for risk aversion and uncertainty as to the payoffs during a conflict, so that initiating a work stoppage involves a non-negligible probability of a lengthy conflict, and/or the wage outcome is uncertain, the fixed costs may be interpreted as the amount that the parties are willing to give up so as to avoid risk (Holden, 1999). Formally, when production is resumed after a work stoppage, the payoffs are $\lambda^{\mathrm{F}} \Pi\left(\mathrm{W}_{\mathrm{j}} / \mathrm{P}, \mathrm{M} / \mathrm{P}\right)$ and $\lambda^{\mathrm{U}} \mathrm{U}\left(\mathrm{W}_{\mathrm{j}} / \mathrm{P}, \mathrm{R}, \mathrm{M} / \mathrm{P}\right)$, where $0<\lambda^{\mathrm{F}}, \lambda^{\mathrm{U}}<1$. (The exact way in which these costs enter does not affect the qualitative results.)

If none of the parties has initiated a work stoppage, there will be a holdout from step 3 on. During a holdout, parties are bound to observe the details of the old contract. 
However, the contract is rarely so specific that it completely determines the parties' payoffs. Workers may reduce profits by use of a variety of different industrial actions (see eg Blanpain, 1994), for example by strictly adhering to the working rules (work-torule). The remuneration of the workers may also consist of some elements that are at the discretion of management, which may be reduced even under the existing contract. Formally, the payoffs during a holdout are $(1-\tau) \Pi\left(\mathrm{W}_{-1}^{\mathrm{U}} / \mathrm{P}, \mathrm{M} / \mathrm{P}\right)$ and $(1-\varepsilon) \mathrm{U}\left(\mathrm{W}_{-1}^{\mathrm{U}} / \mathrm{P}, \mathrm{R}, \mathrm{M} / \mathrm{P}\right)$, where $\tau$ and $\varepsilon$ are parameters satisfying $0<\tau, \varepsilon<1$, reflecting that a holdout is costly. Note that the value of old nominal contract is deflated by the new price level; when analysing the consequences of a deviation from equilibrium in one firm, I take as given equilibrium behaviour in other firms, involving immediate agreement in the wage bargain, with subsequent price setting.

The SPE outcome if holdout threats are used in step 3 is on the form (cf appendix) ${ }^{5}$

$$
\text { (11) } \quad \mathrm{W} / \mathrm{P}=(1+\kappa) \mathrm{W}_{-1}^{\mathrm{U}} / \mathrm{P}, \quad \text { where } \kappa=(\tau-\varepsilon) / 2 .
$$

The wage of the old contract affects the bargaining outcome because it determines players' payoffs during a conflict in the bargaining. (11) allows for a simple interpretation: A holdout leads to higher nominal wages $(\kappa>0)$ if and only if a holdout is more costly to the firm than to the union, ie. $\tau>\varepsilon$ (this is the common assumption in the literature, cf Moene, 1988, Holden, 1989, 1997, and Cramton and Tracy, 1992).

In equilibrium, an agreement will be reached in step 1 or 2 , and there will be no costly dispute. In the appendix, I show the following Proposition.

\footnotetext{
${ }^{5}$ For analytical tractability, (11) is derived by use of linear approximations to the true payoff functions. The qualitative results hold even without using the linear approximation, but the simple and easily interpretable form of (11) would be lost.
} 


\section{Proposition 1}

There exist two critical values $\mathrm{k}^{\mathrm{L}}>\mathrm{k}^{\mathrm{S}}>1$, associated with respectively, lock-out and strike threats, such that the unique SPE outcome to the wage bargaining in firm $\mathrm{j}$ is
(i) "strike case"
If $(1+\kappa) \frac{W^{U}-1}{P}<k^{S} R$,
$\frac{W^{U}}{P}=k^{S} R$
(ii)" holdout case"
If $(1+\kappa) \frac{W^{U}-1}{P} \in\left[k^{S} R, k^{L} R\right]$
$\frac{W^{U}}{P}=(1+\kappa) \frac{W^{U}-1}{P}$
(iii)"lockout case"
If $(1+\kappa) \frac{W^{U}-1}{P}>k^{L} R$,
$\frac{W^{U}}{P}=k^{L} R$

Proposition 1 entails that either player can always ensure the payoff that he would have obtained by initiating a work stoppage - the union can ensure $\mathrm{k}^{\mathrm{S}} \mathrm{R}$ and the firm can push the union down to $\mathrm{k}^{\mathrm{L}} \mathrm{R}$. If an holdout involves a lower payoff to one of the players than he would have gotten from a initiating a work stoppage $\left((1+\kappa) \mathrm{W}_{-1}^{\mathrm{U}} / \mathrm{P}\right.$ is outside the interval $\left.\left[k^{S} R, k^{L} R\right]\right)$, this player can credibly threaten to initiate a work stoppage. The opponent will then concede to a new agreement that gives the threatening player the payoff he would have gotten if work had been stopped. ${ }^{6}$ However, if $(1+\kappa) \mathrm{W}_{-1}^{\mathrm{U}} / \mathrm{P}$ is within the interval $\left[k^{S} R, k^{L} R\right]$, no player can credible threaten to stop work (case (ii)), because both parties lose from actually stopping work. Bargaining is undertaken under holdout threats, as discussed in relation to equation (11) above.

One way to view this is that the player who wants to renegotiate the contract by use of work stoppage threats has a strategic disadvantage. To raise the wage above the outcome from a holdout, the union must threaten to call a costly strike, and the costs

\footnotetext{
${ }^{6}$ From the derivation in appendix it is straightforward to show that $\mathrm{k}^{\mathrm{L}}$ and $\mathrm{k}^{\mathrm{S}}$ are decreasing in $\eta$ and increasing in $\varphi$, implying that the standard feature that the bargaining outcome if strike or lock-out threats prevail is higher, the higher the profit of the firm and higher, the more concerned the union is about wages relative to employment.
} 
associated with calling a strike weaken the potency of this threat. Correspondingly, the costs that the firm incurs by initiating a lock-out weaken the potency of lock-out threats.

As the old contract may affect the bargaining outcome, the parties should ideally take into consideration that the bargaining outcome affects future wage negotiations. This is neglected in the present model. However, in Holden (1997), I analyse an infinitehorizon version of a similar model, where agents take into consideration how the bargaining outcome in one period affects subsequent negotiations. There it is shown that this feature does not affect the qualitative results, only dampens the magnitudes.

We then turn to wage setting in the non-unionised firms. Here, wages are set in an individual bargain between worker and firm. Again, as also assumed by MacLeod and Malcomson (1993), there is an existing nominal wage contract that can only be changed by mutual consent. However, in contrast to the collective bargaining case (and in contrast to the assumptions of MacLeod and Malcomson), it seems less relevant to allow players to stop work temporarily as a means of enforcing a change in the wage (ie. no strike or lockout). On the other hand, terminating the relationship permanently (quits or layoffs) is more relevant than under collective bargaining. If the firm decides to lay off the worker and recruit a new one, I assume that this involves an additional $\operatorname{cost} Z>0$. These costs include possible severance pay, legal costs, as well as the costs of hiring and training a new worker. $\mathrm{Z}$ is clearly increasing in workers' alternative income; for tractability, I assume a proportional relationship, ie $\mathrm{Z}=\mathrm{zR}$, where $\mathrm{z}>0 .{ }^{7}$

\footnotetext{
${ }^{7}$ It would be realistic to assume that $\mathrm{Z}$ also depends on the situation of the firm, as to whether e.g. the firm wants to increase or reduce employment, but such issues are not well captured in a model which is essentially static.
} 
In addition, I assume that there is a potential shirking problem, á lá Shapiro and Stiglitz (1984) (workers' effort is imperfectly monitored), so that the firm must ensure that the wage is sufficiently high that workers do not shirk. If a shirking worker is discovered and fired, he may expect to obtain workers' alternative income R. However, as the probability that a shirker is caught is less than one, the firm must pay more than the expected payoff if being fired. The analysis of this situation is straightforward but cumbersome, and to save space I just postulate a non-shirking constraint à là ShapiroStiglitz (1984) that the wage must satisfy,

$$
\text { (12) } \frac{W^{N}}{P} \geq k^{E} R \quad \mathrm{k}^{\mathrm{E}}>1 \text {. }
$$

Formally, I consider a Rubinstein-type framework where players alternate in making offers. As long as the players are bargaining, both receive the payoff of the existing contract. However, whenever a player has rejected an offer, the player has the option of terminating the relationship permanently. The game thus constitutes a straightforward application of a standard Rubinstein game with outside options, and it follows directly using standard arguments that the outside option principle of Binmore, Shaked and Sutton (1989) applies: the outside options only affect the bargaining outcome if they are better than the "inside" alternative (in this case the payoff of the existing contract). (MacLeod and Malcomson derive a similar result; however, in their model the old contract can also be changed due to threats of stopping work.) Thus, if the real value of the old contract, $\mathrm{W}^{\mathrm{N}}{ }_{-1} / \mathrm{P}$, is below $\mathrm{k}^{\mathrm{E}} \mathrm{R}$, firms will agree to raise the wage so as to avoid shirking. If the real value of the old contract is above $\mathrm{k}^{\mathrm{Z}} \mathrm{R}$, where $\mathrm{k}^{\mathrm{Z}}=\mathrm{k}^{\mathrm{E}}+\mathrm{z}$, firms may 
credibly demand a wage reduction, because in this case it would be less costly to lay off the workers and hire a new one, than to pay the old contract. However, the firm will not be able to push the wage down below $\mathrm{k}^{\mathrm{Z}} \mathrm{R}$, because the worker will reject this. Finally, if $\mathrm{k}^{\mathrm{E}} \mathrm{R} \leq \mathrm{W}^{\mathrm{N}}{ }_{1} / \mathrm{P} \leq \mathrm{k}^{\mathrm{Z}} \mathrm{R}$, neither of the players can credibly demand a wage change, and the old contract will be prolonged. The result is summarised in the following Proposition ${ }^{8}$ :

\section{Proposition 2}

The unique SPE outcome to the wage bargaining in a non-union firm $\mathrm{j}$ is
(i) "efficiency wage case"
If $\frac{W^{N}-1}{P}<k^{E} R$
$\frac{W^{N}}{P}=k^{E} R$
(ii) "holdout case"
If $\frac{W^{N}-1}{P} \in\left[k^{E} R, k^{Z} R\right]$
$\frac{W^{N}}{P}=\frac{W^{N}-1}{P}$
(iii) "layoff case"
If $\frac{W^{N}-1}{P}>k^{Z} R$,
$\frac{W^{N}}{P}=k^{Z} R$

\section{The equilibrium}

We now turn to the equilibrium of the whole economy. For sake of comparison, we first consider an alternative legal regime, which essentially involves the standard assumptions in the literature. In the union sector, I assume exogenously that production cannot take place under the wage negotiations, ruling out the possibility of holdout. In this case the bargaining outcome is given by the Nash bargaining solution where both disagreement points are set to zero, irrespective of the wage of the old contract. As shown in the

\footnotetext{
${ }^{8}$ As under union wage setting, one can show that if both parties can inflict a cost on the opponent without violating the existing contract, the pay changes at a rate $\kappa^{\mathrm{N}}$, ie. $\mathrm{W}^{\mathrm{N}}=$ $\left(1+\kappa^{\mathrm{N}}\right) \mathrm{W}^{\mathrm{N}}{ }_{-1}$. One would expect that individual workers have a weaker position without unions, ie. $\kappa>\kappa^{\mathrm{N}}$. $\kappa^{\mathrm{N}}$ may be positive or negative depending on the institutional framework, like the strictness of employment protection legislation, which provides the worker with scope for reducing effort without being fired. For simplicity, I set $\kappa^{\mathrm{N}}$ to zero.
} 
appendix, the outcome can be written on the form $\mathrm{W}^{\mathrm{U}} / \mathrm{P}=\mathrm{k}^{\mathrm{B}} \mathrm{R}$, where $\mathrm{k}^{\mathrm{L}}>\mathrm{k}^{\mathrm{B}}>\mathrm{k}^{\mathrm{S}}$. In the non-union sector, I assume that employment is at-will, so that the firm may essentially unilaterally set the wage. Furthermore, I neglect other possible costs associated with cutting the wage, like adverse effect on morale etc, in effect setting $\mathrm{z}=0$. In this case the firm will always ensure that the efficiency wage restriction is binding, implying $\mathrm{W}^{\mathrm{N}} / \mathrm{P}=\mathrm{k}^{\mathrm{E}} \mathrm{R}$.

As explained in the Layard, Nickell and Jackman (1991), in wage setting models the equilibrium can be derived by imposing that the real wage that comes out of the wage setting is consistent with the real wage implied by the price setting. Combining (2), (6) and (7), we find that the price setting implies that the aggregate real wage is a constant (because of constant returns to scale and constant elasticity of demand): $\mathrm{W} / \mathrm{P}=1 / \mathrm{v}$. As for the wage setting, we substitute out for $\mathrm{W}^{\mathrm{U}} / \mathrm{P}=\mathrm{k}^{\mathrm{B}} \mathrm{R}$ and $\mathrm{W}^{\mathrm{N}} / \mathrm{P}=\mathrm{k}^{\mathrm{E}} \mathrm{R}$ in (6). The requirement that wage and price setting be consistent thus implies that

$$
\begin{array}{r}
\frac{1}{v}=\frac{W}{P}=\frac{\left(\gamma\left(k^{B} R P\right)^{1-\eta}+(1-\gamma)\left(k^{E} R P\right)^{1-\eta}\right)^{\frac{1}{1-\eta}}}{P}=\left(\gamma\left(k^{B}\right)^{1-\eta}+(1-\gamma)\left(k^{E}\right)^{1-\eta}\right)^{\frac{1}{1-\eta}} R=k^{B E} R \\
\text { where } k^{B E} \equiv\left(\gamma\left(k^{B}\right)^{1-\eta}+(1-\gamma)\left(k^{E}\right)^{1-\eta}\right)^{\frac{1}{1-\eta}}
\end{array}
$$

Substituting out for R using (5), and linearising $\sigma(\mathrm{u}) \equiv \sigma \mathrm{u}$, where $\sigma>0$, to obtain an explicit solution for the equilibrium rate of unemployment, we get

$$
u^{B}=\frac{k^{B E}-1}{\sigma k^{B E}} \frac{1 / v}{1 / v-B}
$$

Observe that, here and below, the equilibrium rate of unemployment exhibits standard properties by being increasing in the markup of wages over workers' alternative income 
$\left(\mathrm{k}^{\mathrm{B}}\right.$ and $\left.\mathrm{k}^{\mathrm{E}}\right)$, and in the payoff of the unemployed $\mathrm{B}$ relative to the average real wage $1 / \mathrm{v}$, and decreasing in the difficulty of finding a new job given the rate of unemployment $(\sigma)$. The rest of the model then follows from straightforward substitution in the relevant equations (cf appendix), and the results are summarised in the following Proposition, involving the standard properties in the literature (as in Layard et al, 1991):

\section{Proposition 3}

In a legal regime where holdout is banned in the union sector, and employment at-will prevails in the non-union sector, the unique equilibrium rate of unemployment is $\mathrm{u}^{\mathrm{B}}$, given by (14). All nominal variables are homogenous of degree one in the nominal money stock, so that the size of the nominal money stock does not affect real variables.

Then return to the main model of the paper. There are now several different types of equilibria, and as will become apparent below, the size of the nominal money stock relative to the nominal wage of the old contracts determines which type prevails. Consider first an equilibrium where strike threats are used in unionised firms, and the efficiency wage applies in the non-union sector. The equilibrium requirement that price setting is consistent with wage setting gives an equation of the same form as (13), which as above can be used to derive the equilibrium rate of unemployment

$$
u^{S}=\frac{k^{S E}-1}{\sigma k^{S E}} \frac{1 / \nu}{1 / \nu-B} \text { where } k^{S E} \equiv\left(\gamma\left(k^{S}\right)^{1-\eta}+(1-\gamma)\left(k^{E}\right)^{1-\eta}\right)^{\frac{1}{1-\eta}}
$$


Comparing (15) and (14) shows that the only one difference between the standard regime and the strike regime is related to $\mathrm{k}^{\mathrm{S}}<\mathrm{k}^{\mathrm{B}}$, implying that $\mathrm{u}^{\mathrm{S}}<\mathrm{u}^{\mathrm{B}}$; the possibility of holdout actually weakens the potency of strike threats (cf. Proposition 1), thus mitigating wage pressure and reducing equilibrium unemployment.

Then consider an equilibrium where lock-out and layoff threats apply in, respectively, union and non-union firms. As above, we can solve for equilibrium unemployment

$$
u^{L}=\frac{k^{L Z}-1}{\sigma k^{L Z}} \frac{1 / v}{1 / v-B} \quad \text { where } k^{L Z} \equiv\left(\gamma\left(k^{L}\right)^{1-\eta}+(1-\gamma)\left(k^{Z}\right)^{1-\eta}\right)^{\frac{1}{1-\eta}}
$$

Comparing (16), (15) and (14) shows that the lock-out equilibrium is associated with higher unemployment than both the strike equilibrium and the standard legal regime, $\mathrm{u}^{\mathrm{L}}>$ $\mathrm{u}^{\mathrm{B}}>\mathrm{u}^{\mathrm{S}}$. This follows from the fact that $\mathrm{k}^{\mathrm{LZ}}>\mathrm{k}^{\mathrm{BE}}>\mathrm{k}^{\mathrm{SE}}$. Intuitively, firms are at a strategic disadvantage in a lock-out equilibrium: In the union sector, the costs associated with initiating a lockout imply that unions can demand a high markup on the alternative income $\left(\mathrm{k}^{\mathrm{L}}>\mathrm{k}^{\mathrm{B}}\right)$; in the non-union sector, the costs of replacing a worker can be exploited by the incumbent worker to obtain a higher wage than would be given to a newcomer $\left(\mathrm{k}^{\mathrm{Z}}>\mathrm{k}^{\mathrm{E}}\right)$, and both these features imply that a higher rate of unemployment is required in equilibrium. Proposition 4 shows that the monetary policy determines which regime prevails (proof in appendix).

\section{Proposition 4}

There is a trade-off between unemployment and inflation over a range of equilibrium rates of unemployment $\left[\mathrm{u}^{\mathrm{S}}, \mathrm{u}^{\mathrm{L}}\right]$, where the outcome depends on the value of the nominal 
money stock. Specifically, there exist critical values $\mathrm{M}^{\mathrm{S}}$ and $\mathrm{M}^{\mathrm{L}}$, and associated inflation rates $\pi^{\mathrm{S}}$ and $\pi^{\mathrm{L}}$, where $\mathrm{M}^{\mathrm{S}}>\mathrm{M}^{\mathrm{L}}, \pi^{\mathrm{S}}>\pi^{\mathrm{L}}$, and $\pi^{\mathrm{S}}>0$, such that

(i) If $\mathrm{M}>\mathrm{M}^{\mathrm{S}}$, strike threats prevail in the union sector, efficiency wages in the non-union sector, inflation $\mathrm{P}_{/} \mathrm{P}_{-1}-1 \geq \pi^{\mathrm{S}}$, and the rate of unemployment, $\mathrm{u}=\mathrm{u}^{\mathrm{S}}$. If $\mathrm{M} \in\left[\mathrm{M}^{\mathrm{L}}, \mathrm{M}^{\mathrm{S}}\right]$, holdout threats prevail in at least one sector, inflation $\mathrm{P} / \mathrm{P}_{-1}-1$ $\in\left[\pi^{\mathrm{L}}, \pi^{\mathrm{S}}\right]$, and the rate of unemployment $\mathrm{u} \in\left[\mathrm{u}^{\mathrm{S}}, \mathrm{u}^{\mathrm{L}}\right]$.

(iii) If $\mathrm{M}<\mathrm{M}^{\mathrm{L}}$, lock-out threats prevail in the union sector, and layoff threats in the non-union sector, inflation $\mathrm{P} / \mathrm{P}_{-1}-1 \leq \pi^{\mathrm{L}}$, and the rate of unemployment, $\mathrm{u}=\mathrm{u}^{\mathrm{L}}$.

Proposition 4 entails important non-linearities between monetary policy, inflation and industrial action. In the low unemployment equilibrium, $\mathrm{u}=\mathrm{u}^{\mathrm{S}}$, strike threats must prevail in the unionised sector, and efficiency wages in the non-union sector. As all unions can obtain a nominal wage $(1+\kappa) \mathrm{W}_{-1}^{\mathrm{U}}$ by a holdout, strike threats must give at least this wage, and this puts a lower bound on the rate of inflation. Specifically, if money growth is sufficiently high to involve inflation greater than $\pi^{S}$, (which is equivalent to $M>M^{S}$ ), the economy will be in the "strike" regime.

Likewise, the high unemployment equilibrium, $\mathrm{u}=\mathrm{u}^{\mathrm{L}}$, is associated with lock-out threats in union firms, and the layoff case in non-union firms. Firms can credibly cut wages from the level associated with the old contract, which will happen if money growth is so low that inflation is below $\pi^{\mathrm{L}}$, ie that $\mathrm{M}<\mathrm{M}^{\mathrm{L}}$.

For intermediate levels of the money stock, $M \in\left[\mathrm{M}^{\mathrm{L}}, \mathrm{M}^{\mathrm{S}}\right]$, inflation is between the critical rates $\pi^{\mathrm{L}}$ and $\pi^{\mathrm{S}}$, so that nominal rigidity is binding in at least one sector, while 
unemployment takes an intermediate value, between $u^{\mathrm{S}}$ and $\mathrm{u}^{\mathrm{L}}$. (McDonald, 1995) surveys other theories of a range of equilibria.)

\section{$6 \quad$ Simulation results}

Proposition 4 above establishes the existence of the long run trade-off between inflation and unemployment. Moreover, a comparison with Proposition 3 shows that the possibility of holdout threats and the existence of firing costs hold the key to the long run effects of monetary policy. However, the practical importance of these results depends on the quantitative effects; this is the topic of the numerical simulations presented in this section. Here I also allow for additional features that are not included in the theoretical model. First, productivity growth leads to growth in real wages, allowing for growth in nominal wages even at constant nominal prices. I include annual labour productivity growth at a rate $\alpha=0.02$. Second, there is heterogeneity at industry/firm level, involving changes in relative wages: I distinguish five groups within each sector, unionised and non-unionised, and add a group-specific stochastic term (standard error 0.01) to the bargaining outcome except in the holdout cases (cf appendix).

Figure 2 shows the trade-off between inflation and unemployment in the form of a long-run Phillips curve under the basis simulation (see also Table 1, column 2). While I have tried to choose parameter values that are plausible for most European countries, the highly stylised nature of the model implies that the position of the Phillips curve, as well as the entries in Table 1, should only be considered as illustrative.

According to the basis simulation, inflation can be reduced down to 1.9 percent on annual basis with only a small increase in unemployment, from 6.5 to 6.7 percent. However, a further reduction in inflation involves a larger increase in unemployment, by 
almost $1 / 2$ percentage points (to 6.9 percent) at inflation of 1.4 percent, and by 2.5 percentage point (to 9.2 percent) at 1 percent inflation. Absolute price stability - zero inflation - involves in increase in unemployment of more than 3.5 percentage points, up to 10.2 percent. (Incidentally, Lundborg and Sacklèn, 2001, find in a study of Sweden for the period 1963 - 2000 that a reduction in inflation from about $21 / 2$ percent to zero is associated with an increase in unemployment of more than two percentage points.)

The remaining columns in Table 1 show the results of variation in some of the parameter values. The third to fifth columns show that the size of the unionised sector $(\gamma)$ has fairly small effect for moderate and high levels of inflation, even a dramatic reduction in coverage of collective agreements from a stylised European country (the base case, $\gamma=$ $0.75)$ to a stylised US type of economy $(\gamma=0.15)$, combined with imposing employment at-will outside the union sector (allowing for a small cost associated with cutting wages, eg related to fairness, etc. so that $\mathrm{z}=0.01$ ), only reduces unemployment by about 1 percentage point if inflation is 2.5 percent or above. However, for very low rates of inflation the difference is much greater - at zero inflation unemployment is more than 4 percent higher in the stylised European base case than in the US type economy. In fact, negative inflation involves only a relatively small increase in unemployment in the US type economy, reflecting the small size of the union sector.

The consequences of price stability or negative inflation increase dramatically if a lock-out is very costly or difficult for the employer (the $\lambda^{\mathrm{L}}=0.8$ column). This may be a plausible feature of several southern European countries where the law puts severe restrictions to firms' use of lock-out (in contrast to the situation in the US and the UK). 
Setting nominal wage growth under holdout threats to zero, $(\kappa=0)$, moves the Phillips curve downwards, implying that inflation can be pushed down to minus 1.5 percent without much increase in unemployment. This illustrates that the extent to which unions can use non-strike industrial action to push up nominal wages is a crucial factor when evaluating the implications of price stability.

Productivity growth is another key factor, as it in the long run has a direct onefor-one effect on the vertical position of the Phillips curve. With no productivity growth, $\alpha=0$, unemployment increases significantly for inflation rates below 3.4 percent, and even 1.9 percent inflation involves a rise in unemployment of almost 4 percentage points.

The right column (EMU) captures one of the additional problems by pursuing a common monetary policy in a Monetary Union. Here, the entries show the average rate of unemployment for 12 base case countries, where persistent country-specific annual money shocks are added to the common union money stock. As the Phillips curve is convex for inflation rates above 1 percent (cf Figure 2), the existence of demand shocks inducing variability in inflation rates across countries raises union-wide unemployment within this range. Now, 1.9 percent inflation involves 0.5 percentage points higher unemployment than for inflation above 3.9 (7.1 versus 6.6), while 1.4 percent inflation increases unemployment by another 0.7 percentage point, to 7.8 percent.

Table 2 presents the proportion of nominal wage cuts under different rates of inflation. The numbers should only be taken as an illustration, as they clearly hinge on fairly arbitrary parameter values. Somewhat surprisingly, higher coverage of collective agreements increases the proportion of nominal wage cuts under negative inflation. The reason is simple, higher coverage also implies higher unemployment and that a larger 
share of the economy may use inflationary work-to-rule, implying a stronger downward pressure on the rest of the economy. Note, however, that adding an idiosyncratic, individual-specific component to the wage setting would lead to additional wage cuts, in particular in the non-union sector. As expected, weaker employment protection legislation, $\mathrm{z}=0.01$, leads to a higher proportion of nominal wage cuts.

\section{$7 \quad$ Empirical relevance}

The model entails a number of predictions that can be tested empirically. First, the model predicts that downward nominal wage rigidity exists, but is not absolute (wage cuts do occur). This is consistent with the findings of a number of recent studies, for many different countries: Fehr and Goette (2000) for Switzerland, Beissinger and Knoppik (2000) and Knoppik and Beissinger (2001) for Germany, Dessy (1999) for Italy (as reported in Kramarz, 2001) Christofides and Leung (1999), and Fortin and Dumont (2000) for Canada, Holden (1998) for the manufacturing sectors in the Nordic countries, Agell and Lundborg (1999) for Sweden, Kimura and Ueda (1997) for Japan, Nickell and Quintini (2001) for the UK, and Altonji and Devereux (1999) and Lebow et al (2000) for the US (the latter three papers also discuss previous empirical findings for the UK and the US). In general these studies find (i) a spike in the distribution of nominal wage changes at zero and (ii) that the rate of inflation affects the distribution of nominal wage changes. These findings are consistent with the model here, but not with standard models with overlapping wage contracts where the rate of inflation per se is irrelevant.

Secondly, the model predicts that, cet. par., downward nominal rigidity is likely to be stronger the higher the coverage of collective agreements and the more strict the employment protection legislation. The stronger rigidity under collective agreements do 
not prevent nominal wage cuts from taking place, but it entails that higher unemployment is required. Regrettably, different methods and data in the above-mentioned studies make it difficult to compare the degree of downward nominal wage rigidity across countries. However, the studies nevertheless indicate that money wage rigidity is stronger in Sweden and Italy than in the UK and the US, precisely in line with this prediction, in light of the much stronger employment protection legislation and higher coverage rates of collective agreements in Sweden and Italy. Bewley (1999, table 11.1) find in a survey of businesses in the Northeast of the US that 10 percent of the businesses had a cut in the base pay for some or all employees during the recession in the early 1990s. In contrast, Agell and Lundborg (1999), based on survey evidence among managers in Swedish firms with a total of 187000 employees, find that nominal wage cuts were virtually absent in the 1990s, in spite of soaring unemployment and several years with close to zero inflation. Note, however, that the fact that downward nominal rigidity is found also in countries with weak legal protection of workers' nominal wages, as in the US and Switzerland, suggests that also fairness considerations are of importance.

Third, the model predicts that low inflation is associated with lower output and employment in many European countries, but less so in the US. This prediction is consistent with evidence in Bullard and Keating (1995). Studying the long run relationship between inflation and output in 58 countries over the period 1960-90, Bullard and Keating find 16 countries that have experienced permanent shocks to both inflation and the level of output. Of these 16 countries, Bullard and Keating find a positive and significant long-run response of the level of real output to a permanent inflation shock for the four European countries with the lowest rates of inflation 
(Germany, Austria, Finland and the UK, neglecting Cyprus where the positive coefficient is insignificant due to a very large confidence interval). However, for the US, which incidentally also had low inflation, the permanent shock to inflation had no significant permanent effect on output (the point estimate being close to zero).

\section{$8 \quad$ Concluding remarks}

Recent empirical studies have shown substantial evidence of downward nominal wage rigidity in a number of OECD countries. Drawing upon earlier work by MacLeod and Malcomson (1993) and Holden (1994), I show that this can be explained by the institutional feature of European labour markets that nominal wages are a part of a contract, either a collective agreement or an individual employment contract, and can as such only be changed by mutual consent. This legal feature implies that workers have a strategic advantage in the wage negotiations when they try to prevent a cut in nominal wages. The upshot is a long run trade-off between inflation and unemployment, where very low or negative inflation is associated with higher unemployment.

The analysis shows that workers protected by collective agreements or strict employment protection legislation are in a stronger position when trying to prevent nominal wage cuts, implying that that the extent of downward nominal wage rigidity is related to the coverage of collective agreements and the strictness of the employment protection legislation. This prediction is consistent with empirical evidence that downward nominal wage rigidity is much stronger in Sweden and Italy than in the UK and the US.

To illustrate the macroeconomics implications of these features, the model is used for simple numerical illustrations. Given the stylised nature of the model, the results 
should only be considered indicative. The numerical simulations suggest that even in a typical European economy, with high coverage of collective agreements and some employment protection legislation, annual inflation can in normal times be kept as low as 2 - 2.5 percent with negligible costs in the form of additional unemployment. For lower rates of inflation, downward nominal rigidity may bind in parts of the labour market, leading to stronger wage pressure and higher unemployment. In times of low productivity growth, downward nominal wage rigidity may be binding for higher rates of inflation, and even 2 percent inflation may involve a considerable increase in unemployment. In contrast, in countries with lower bargaining coverage, and much weaker employment protection legislation, inflation may even be set to zero with only limited increase in unemployment (A caveat to this conclusion is that fairness considerations may limit nominal wage cuts, so that low inflation may lead to higher unemployment also here).

In the European Monetary Union, an additional problem may occur due to asymmetric shocks. For inflation rates for which nominal rigidities bind in parts of the labour market, the long run Phillips curve is convex, implying that asymmetric shocks involve a worsening of the trade-off between inflation and unemployment. In this case countries experiencing a positive nominal demand shock will have higher inflation, with little reduction in unemployment, whereas countries experiencing a negative nominal demand shock will have higher unemployment with little reduction in unemployment. A consequence of this is that additional unemployment may occur for somewhat higher rates of inflation than if the monetary policy could be set specifically for each country.

The costs associated with higher unemployment under very low inflation will clearly induce changes in the way labour markets operate. One would expect pay systems 
to become more flexible, for example by more extensive use of bonus systems (leading to a reduction in the nominal wage increase under holdouts, $\kappa$ ), which would mitigate the inflation bias. One would also expect more use of temporary employments contracts (Holden, 2001), a tendency that has taken place in many European countries over the last decades. However, it is difficult to predict how far-reaching the changes will be. As observed above, the legal rule that contract renegotiations require mutual consent plays an important role in ensuring efficient investments. Furthermore, restrictions on the employer's right to unilaterally cut nominal wages seem a key ingredient if employment protection legislation is to be effective. Thus, proposals for changes in labour laws are likely to be met by strong resistance by unions and insiders.

The key alternative explanation of downward nominal wage rigidity is fairness considerations. In my view, these two explanations should be seen as complementary rather than alternative. In particular, it seems plausible that they may strengthen each other in the sense that the existence of both makes either more persistent: The fact that many labour market participants find nominal wage cuts unfair may also contribute to the continued existence of legal protection of nominal wages. The legal protection of nominal wages makes wage cuts rare even in a low-inflation environment, thus preventing Gordon's (1996) argument that the fairness considerations will be undermined by wage cuts being "too common". The extensive downward nominal wage rigidity in Sweden and Switzerland documented by Agell and Lundborg (1999) and Fehr and Goette (2000), even after years of close to zero inflation and high unemployment, also show that rigidities may be highly persistent. 


\section{Appendix}

\section{Derivation of (11), the outcome of the wage bargaining during a holdout}

The real wage outcome under holdout threats is given by (as noted below, the limit case of the Rubinstein model corresponds to the Nash bargaining solution)

$$
\begin{aligned}
& \mathrm{W}_{\mathrm{j}} / \mathrm{P}=\arg \max \left[\Pi\left(\mathrm{W}_{\mathrm{j}} / \mathrm{P}, \mathrm{M} / \mathrm{P}\right)-(1-\tau) \Pi\left(\mathrm{W}_{-1}^{\mathrm{U}} / \mathrm{P}, \mathrm{M} / \mathrm{P}\right)\right] \\
& {\left[\mathrm{U}\left(\mathrm{W}_{\mathrm{j}} / \mathrm{P}, \mathrm{R}, \mathrm{M} / \mathrm{P}\right)-(1-\varepsilon) \mathrm{U}\left(\mathrm{W}_{-1}^{\mathrm{U}} / \mathrm{P}, \mathrm{R}, \mathrm{M} / \mathrm{P}\right)\right]}
\end{aligned}
$$

Using linear approximations to the true payoff functions, ie.

$$
\Pi\left(\mathrm{W}^{\mathrm{U}}{ }_{-1} / \mathrm{P}, \mathrm{M} / \mathrm{P}\right) \approx \Pi_{\mathrm{w}} \mathrm{W}_{-1}^{\mathrm{U}} / \mathrm{P} \text { and } \mathrm{U}\left(\mathrm{W}^{\mathrm{U}}{ }_{-1} / \mathrm{P}, \mathrm{R}, \mathrm{M} / \mathrm{P}\right) \approx \mathrm{U}_{\mathrm{w}} \mathrm{W}^{\mathrm{U}}{ }_{-1} / \mathrm{P},
$$

the Nash bargaining solution (17) reads (omitting subscript indicating firm)

$$
\begin{aligned}
& \mathrm{W}_{\mathrm{j}} / \mathrm{P}=\arg \max \left[\left(\mathrm{W}_{\mathrm{j}} / \mathrm{P}-\mathrm{W}_{-1}^{\mathrm{U}} / \mathrm{P}\right) \Pi_{\mathrm{w}}+\tau \Pi\left(\mathrm{W}_{-1}^{\mathrm{U}} / \mathrm{P}, \mathrm{M} / \mathrm{P}\right)\right] \\
& \quad\left[\left(\mathrm{W}_{\mathrm{j}} / \mathrm{P}-\mathrm{W}_{-1}^{\mathrm{U}} / \mathrm{P}\right) \mathrm{U}_{\mathrm{W}}+\varepsilon \mathrm{U}\left(\mathrm{W}^{\mathrm{U}}{ }_{-1} / \mathrm{P}, \mathrm{R}, \mathrm{M} / \mathrm{P}\right)\right] .
\end{aligned}
$$

The first order condition can be rearranged to

$$
\frac{W_{j}}{P}=\frac{W^{U}-1}{P}+\frac{1}{2}\left(\frac{\pi \Pi\left(W^{U}{ }_{-1} / P, M / P\right)}{\Pi_{w}}-\frac{\varepsilon U\left(W_{-1}^{U} / P, R, M / P\right)}{U_{w}}\right)
$$

which can be reduced to (11) (invoking the same linear approximations). QED

\section{Proof of Proposition 1}

To find the SPE outcome, we must analyse the game backwards. As of step 3, we have the Rubinstein (1982) bargaining game. Binmore, Rubinstein and Wolinsky (1986) show that in the limit when the time delay between offers converges to zero, the outcome is 
given by the Nash bargaining solution (assuming for simplicity that players have equal discount factors). If a work stoppage is initiated, the bargaining outcome is given by

$$
\frac{W_{j}}{P}=\arg \max \lambda^{F} \Pi\left(\frac{W_{j}}{P}, \frac{M}{P}\right) \lambda^{U} U\left(\frac{W_{j}}{P}, R, \frac{M}{P}\right)
$$

Substituting out for (9) and (10), the first order condition can be solved for

$$
\frac{W_{j}}{P}=k^{B} R, \quad \text { where } \quad k^{B} \equiv \frac{2 \eta-\eta \varphi-1}{2 \eta-\eta \varphi-1-\varphi}>1
$$

Consider now the choice of the parties whether to initiate a work stoppage in step 1 or 2 . Clearly, no party will initiate a work stoppage, leading to a costly dispute, if he/she can obtain higher payoff by renegotiation under a holdout. To formalise this intuition, define two critical values $\omega^{\mathrm{L}}$ and $\omega^{\mathrm{S}}$ for the real wage outcome by the following equations

$$
\begin{aligned}
& \Pi\left(\omega^{L}, M / P\right)=\lambda^{F} \Pi\left(k^{B} R, M / P\right) \\
& U\left(\omega^{S}, R, M / P\right)=\lambda^{U} U\left(k^{B} R, R, M / P\right)
\end{aligned}
$$

The firm can obtain a payoff $\lambda^{\mathrm{F}} \Pi\left(\mathrm{k}^{\mathrm{B}} \mathrm{R}, \mathrm{M} / \mathrm{P}\right)$ by initiating a work stoppage. If $(1+\kappa) \mathrm{W}^{\mathrm{U}}{ }_{-1} / \mathrm{P} \leq \omega^{\mathrm{L}}$, the firm obtains at least as high profits by a holdout leading to a new agreement on $(1+\kappa) \mathrm{W}_{-1}^{\mathrm{U}} / \mathrm{P}$ than by initiating a work stoppage. Likewise, if $(1+\kappa) \mathrm{W}_{-1}^{\mathrm{U}} / \mathrm{P} \geq \omega^{\mathrm{S}}$, the union obtains at least as high utility from a holdout as from initiating a work stoppage. From the fact that $\partial \Pi / \partial(\mathrm{Wj} / \mathrm{P})<0, \partial \mathrm{U} / \partial(\mathrm{Wj} / \mathrm{P})>0$ and $\lambda^{\mathrm{U}}, \lambda^{\mathrm{F}}$ $<1$, it is immediate that $\omega^{\mathrm{S}}<\mathrm{k}^{\mathrm{B}} \mathrm{R}<\omega^{\mathrm{L}}$ for all $\mathrm{R}$. 
Let me then prove that $\omega^{\mathrm{L}}$ and $\omega^{\mathrm{S}}$ are linear functions of $\mathrm{R}, \omega^{\mathrm{L}}=\mathrm{k}^{\mathrm{L}} \mathrm{R}$ and $\omega^{\mathrm{S}}=\mathrm{k}^{\mathrm{S}} \mathrm{R}$. To show this, note that substituting out for $\Pi$ using (9), (21) can be solved for

$$
\omega^{L}(R)=k^{L} R \quad \text { where } k^{L} \equiv\left(\lambda^{F}\right)^{\frac{1}{1-\eta}} k^{B}
$$

To verify the same property for $\omega^{S}$, substitute out for $(10)$ in $(22)$ to obtain $\left(\omega^{S}-R\right)\left(\omega^{S}\right)^{-\eta}=$ $\lambda^{\mathrm{S}}\left(\mathrm{k}^{\mathrm{B}} \mathrm{R}-\mathrm{R}\right)\left(\mathrm{k}^{\mathrm{B}} \mathrm{R}\right)^{-\eta}$. Dividing by $\mathrm{R}^{1-\eta}$, we obtain $\left(\left(\omega^{\mathrm{S}} / \mathrm{R}\right)-1\right)\left(\omega^{\mathrm{S}} / \mathrm{R}\right)^{-\eta}=\lambda^{\mathrm{S}}\left(\mathrm{k}^{\mathrm{B}}-1\right)\left(\mathrm{k}^{\mathrm{B}}\right)^{-\eta}$, which determines a unique value for $\left(\omega^{S} / R\right)$ in the appropriate interval for $\omega^{S} / R$ (which is $(1, v))$, validating the assumption that $\omega^{\mathrm{S}}$ is a linear function of $\mathrm{R}, \omega^{\mathrm{S}}=\mathrm{k}^{\mathrm{S}} \mathrm{R}$.

I now complete the proof by sketching the equilibrium path. (It is straightforward to show that a deviation would hurt the deviator.)

Case (i), The firm offers $\mathrm{k}^{\mathrm{S}} \mathrm{R}$, which is immediately accepted by the union.

Case (ii), Any offer different from $(1+\kappa) \mathrm{W}_{-1}^{\mathrm{U}} / \mathrm{P}$ is rejected, with no work stoppage. Case (iii), There are two alternative equilibrium paths, leading to the same outcome. One path is that the firm offers $\mathrm{k}^{\mathrm{L}} \mathrm{R}$, which the union accepts. The other is that the firm offers less, is rejected by the union, and then the union offers $\mathrm{k}^{\mathrm{L}} \mathrm{R}$ which the firm accepts. QED

\section{Proof of Proposition 3}

The real wages in the two sectors are found by inserting $\mathrm{u}^{\mathrm{B}}$ in the expression for $\mathrm{R}$, to obtain $\mathrm{W}^{\mathrm{UB}} / \mathrm{P}=\mathrm{k}^{\mathrm{B}} \mathrm{R}^{\mathrm{B}}$, and $\mathrm{W}^{\mathrm{NB}} / \mathrm{P}=\mathrm{k}^{\mathrm{E}} \mathrm{R}^{\mathrm{B}}$, where $\mathrm{R}^{\mathrm{B}} \equiv\left(1-\mathrm{u}^{\mathrm{B}}\right) / v+\mathrm{u}^{\mathrm{B}} \mathrm{B}$. Output levels in the two sectors are $\mathrm{Y}^{\mathrm{UB}}=\gamma\left(v \mathrm{k}^{\mathrm{B}} \mathrm{R}^{\mathrm{B}}\right)^{-\eta}(\mathrm{M} / \mathrm{P})$ and $\mathrm{Y}^{\mathrm{NB}}=(1-\gamma)\left(v \mathrm{k}^{\mathrm{E}} \mathrm{R}^{\mathrm{B}}\right)^{-\eta}(\mathrm{M} / \mathrm{P})$. To find the equilibrium value for the real money stock, we substitute out for sectoral employment in the definition of the rate of unemployment, using that $\mathrm{Y}^{\mathrm{U}}=\mathrm{N}^{\mathrm{U}}$ and $\mathrm{Y}^{\mathrm{N}}=\mathrm{N}^{\mathrm{N}}$, ie

$$
u^{B}=1-Y^{U B}-Y^{N B}=1-\gamma\left(v k^{B} R^{B}\right)^{-\eta}(M / P)-(1-\gamma)\left(v k^{E} R^{B}\right)^{-\eta}(M / P) .
$$


Rearranging, we find the equilibrium real money stock as

$$
\left(\frac{M}{P}\right)^{B}=\frac{1-u^{B}}{\gamma\left(v k^{B} R\right)^{-\eta}+(1-\gamma)\left(\nu k^{E} R\right)^{-\eta}}
$$

It follows that the equilibrium price level is homogenous of degree one in the nominal money stock, $\mathrm{P}=\left[1 /(\mathrm{M} / \mathrm{P})^{\mathrm{B}}\right] \mathrm{M}$, and so are all other nominal variables. The real variables are derived by inserting for $(\mathrm{M} / \mathrm{P})^{\mathrm{B}}$ in the relevant expressions.

\section{Proof of Proposition 4}

Part (i): Analogously to the proof of Proposition 3, the equilibrium level of the real money stock associated with equilibrium where strike threats and efficiency wages prevail, is given by (with obvious notation)

$$
\left(\frac{M}{P}\right)^{S}=\frac{1-u^{S}}{\gamma\left(v k^{S} R\right)^{-\eta}+(1-\gamma)\left(v k^{E} R\right)^{-\eta}}
$$

In an equilibrium where strike threats and efficiency wages prevail, the nominal wages in the two sectors are functions of the nominal money stock

$$
\begin{aligned}
& W^{U S}=k^{S} R^{S} P=k^{S} R^{S} \frac{1}{(M / P)^{S}} M \\
& W^{N S}=k^{E} R^{S} P=k^{E} R^{S} \frac{1}{(M / P)^{S}} M
\end{aligned}
$$

The critical value $\mathrm{M}^{\mathrm{S}}$, given by $\mathrm{M}^{\mathrm{S}}=\max \left[\mathrm{M}^{\mathrm{US}}, \mathrm{M}^{\mathrm{NS}}\right]$, where $\mathrm{M}^{\mathrm{US}}$ is given by

$$
\mathrm{W}^{\mathrm{US}}=\mathrm{k}^{\mathrm{S}} \mathrm{R}^{\mathrm{S}} \mathrm{M}^{\mathrm{US}} /(\mathrm{M} / \mathrm{P})^{\mathrm{S}}=\left(1+\kappa^{\mathrm{U}}\right) \mathrm{W}_{-1}^{\mathrm{U}}
$$

Or, solving for $\mathrm{M}^{\mathrm{US}}$, 


$$
\mathrm{M}^{\mathrm{US}}=(\mathrm{M} / \mathrm{P})^{\mathrm{S}}\left(1+\kappa^{\mathrm{U}}\right) \mathrm{W}_{-1}^{\mathrm{U}} /\left(\mathrm{k}^{\mathrm{S}} \mathrm{R}^{\mathrm{S}}\right)
$$

Likewise, $\mathrm{M}^{\mathrm{NS}}$ is given by

$$
\mathrm{M}^{\mathrm{NS}}=(\mathrm{M} / \mathrm{P})^{\mathrm{S}} \mathrm{W}^{\mathrm{N}}{ }_{-1} /\left(\mathrm{k}^{\mathrm{E}} \mathrm{R}^{\mathrm{S}}\right)
$$

From the definitions of $\mathrm{M}^{\mathrm{S}}, \mathrm{M}^{\mathrm{US}}$ and $\mathrm{M}^{\mathrm{NS}}$, it is now clear that $\mathrm{W}^{\mathrm{US}}>\left(1+\kappa^{\mathrm{U}}\right) \mathrm{W}_{-1}^{\mathrm{U}}$ and $\mathrm{W}^{\mathrm{NS}}>\mathrm{W}^{\mathrm{N}}{ }_{-1}$ for all $\mathrm{M}>\mathrm{M}^{\mathrm{S}}$. Using the results of Propositions 1 and 2, this implies that strike threats and efficiency wages prevail if $\mathrm{M}>\mathrm{M}^{\mathrm{S}}$, which again implies (as derived in the main text) that $u=u^{\mathrm{S}}$. The minimum associated rate of inflation, $\pi^{\mathrm{S}}$, is then given by $\pi^{\mathrm{S}}=\mathrm{P} / \mathrm{P}_{-1}-1=\left[1 /(\mathrm{M} / \mathrm{P})^{\mathrm{S}}\right] \mathrm{M}^{\mathrm{S}} / \mathrm{P}_{-1}-1$. This completes the proof of part (i).

Part (iii): The proof is analogous to the proof of part (i): just define $\mathrm{M}^{\mathrm{L}}=\min \left[\mathrm{M}^{\mathrm{UL}}, \mathrm{M}^{\mathrm{NL}}\right.$ ] and replace superscript $\mathrm{S}$ with superscript $\mathrm{L}$, and superscript $\mathrm{E}$ with superscript $\mathrm{Z}$, in equations (26) - (31)). We then find that $\mathrm{W}^{\mathrm{UL}}<\left(1+\kappa^{\mathrm{U}}\right) \mathrm{W}^{\mathrm{U}}{ }_{-1}$ and $\mathrm{W}^{\mathrm{NL}}<\mathrm{W}^{\mathrm{N}}{ }_{-1}$ for all $\mathrm{M}<$ $\mathrm{M}^{\mathrm{L}}$. $\pi^{\mathrm{L}}$ is given analogously to $\pi^{\mathrm{S}}$, by $\pi^{\mathrm{L}}=\left[1 /(\mathrm{M} / \mathrm{P})^{\mathrm{L}}\right] \mathrm{M}^{\mathrm{L}} / \mathrm{P}_{-1}-1$.

Part (ii): As inflation is increasing monotonically in $\mathrm{M}$, it follows that $\pi$ is in the interval $\left[\pi^{\mathrm{L}}, \pi^{\mathrm{S}}\right]$, for all $\mathrm{M}$ satisfying $\mathrm{M}^{\mathrm{L}} \leq \mathrm{M} \leq \mathrm{M}^{\mathrm{S}}$. From the proofs of part (i) and (iii), it also follows that holdout threats prevail in at least one sector. The contention that $u \in\left[u^{S}, u^{L}\right]$ follows from the fact that if $\mathrm{u}<\mathrm{u}^{\mathrm{S}}$, then $\mathrm{W}^{\mathrm{US}}>\left(1+\kappa^{\mathrm{U}}\right) \mathrm{W}^{\mathrm{U}}-1$ and $\mathrm{W}^{\mathrm{NS}}>\mathrm{W}^{\mathrm{N}}{ }_{-1}$ so that holdout threats does not apply in either sector; correspondingly, if $\mathrm{u}>\mathrm{u}^{\mathrm{L}}$, then $\mathrm{W}^{\mathrm{UL}}<$ $\left(1+\kappa^{\mathrm{U}}\right) \mathrm{W}^{\mathrm{U}}-1$ and $\mathrm{W}^{\mathrm{NL}}<\mathrm{W}^{\mathrm{N}}{ }_{-1}$ so that holdout threats does not apply in either sector. QED 


\section{Numerical simulations}

The numerical simulations are done in the Nonlinear application in Gauss, based on the following equations (firms $\mathrm{i}=1-5$ are unionised, 6-10 non-unionised).

$$
\left.P=\left(0.2 \gamma\left(P_{1}^{1-\eta}+P_{2}^{1-\eta}+P_{3}^{1-\eta}+P_{4}^{1-\eta}+P_{5}^{1-\eta}\right)+0.2(1-\gamma)\left(P_{6}^{1-\eta}+P_{7}^{1-\eta}+P_{8}^{1-\eta}+P_{9}^{1-\eta}+P_{10}^{1-\eta}\right)\right)\right)^{\frac{1}{1-\eta}}
$$

$$
\left.W=\left(0.2 \gamma\left(W_{1}^{1-\eta}+W_{2}^{1-\eta}+W_{3}^{1-\eta}+W_{4}^{1-\eta}+W_{5}^{1-\eta}\right)+0.2(1-\gamma)\left(W_{6}^{1-\eta}+W_{7}^{1-\eta}+W_{8}^{1-\eta}+W_{9}^{1-\eta}+W_{10}^{1-\eta}\right)\right)\right)^{\frac{1}{1-\eta}}
$$

$$
R=R\left(u, \frac{W}{P}\right) \equiv(1-\sigma u) \frac{W}{P}+\sigma u B,
$$

$$
\mathrm{u}=1-\mathrm{N}=1-\Sigma_{\mathrm{j}} \mathrm{N}_{\mathrm{j}}
$$

$\mathrm{P}_{\mathrm{i}}=v \mathrm{~W}_{\mathrm{i}}$, where $v=\eta /(\eta-1)>1$.

$$
W_{i}^{U S}=k^{S} R P\left(1+\tilde{d}_{i}\right) \quad \mathrm{i}=1,2,3,4,5
$$

$$
W_{i}^{U H}=\left(1+\kappa^{U}\right) W_{i ;-1}^{U}
$$

$$
W_{i}^{U L}=k^{L} R P\left(1+\tilde{d}_{i}\right)
$$

$$
W_{i}=\max \left[W_{i}^{U S} \min \left[W_{i}^{U H}, W_{i}^{U L}\right]\right] \quad \mathrm{i}=1,2,3,4,5
$$

$$
W_{i}^{N S}=k^{E} R P\left(1+\tilde{d}_{i}\right) \quad \mathrm{i}=6,7,8,9,10
$$

$W_{i}^{N H}=W_{i ;-1}^{N}$

$$
W_{i}^{N L}=k^{Z} R P\left(1+\tilde{d}_{i}\right)
$$

$$
W_{i}=\max \left[W_{i}^{N S} \min \left[W_{i}^{N H}, W_{i}^{N L}\right]\right] \quad \mathrm{i}=6,7,8,9,10
$$

$$
N_{i}=\frac{1}{(1+\alpha)}\left(\frac{P_{i}}{P}\right)^{-\eta} \frac{\gamma}{5} \frac{M}{P} \quad \mathrm{i}=1,2,3,4,5
$$

$$
N_{i}=\frac{1}{(1+\alpha)}\left(\frac{P_{i}}{P}\right)^{-\eta} \frac{1-\gamma}{5} \frac{M}{P} \quad \mathrm{i}=6,7,8,9,10
$$

$$
M=M_{-1}(1+g)
$$$$
M_{j}=M_{j,-1}\left(1+g_{j}\right)
$$

$$
g_{j}=g+s_{j} \quad \text { where } \quad s_{j}=0.67 * s_{j,-1}+0.01 * v, v \sim N(0,1) \mathrm{j}=1, . .12
$$


In the EMU simulation, (47) and (48) replace (46) to give the nominal money stock, and (31)-(45), (46)-(46) are solved for 12 different countries.

To ensure that the shock to relative wages, $\widetilde{d}_{i}$, is basically exactly that, I use an auxiliary variable $\hat{d}_{i}$ which is independently and normally distributed with zero expectation and variance 0.01 . Then, I define the average shock $\bar{d}=\frac{1}{10} \sum_{i} \hat{d}_{i}$, and let $\widetilde{d}_{i}=\hat{d}_{i}-\bar{d}$.

To avoid noise arising from stochastic wage setting and initial conditions, I let the economy run for 55 periods, with an exogenous money growth rate $g$ that determines the rate of inflation. The entries in Table 1 are the average rate of unemployment over the last 50 periods. In the EMU simulations, the entry is the average for all 12 countries.

To calculate the proportion of nominal wage cuts, I define a dummy variable $D_{i}=1$ if $\mathrm{W}_{\mathrm{it}-1}>\mathrm{W}_{\mathrm{it}}, \mathrm{i}=1,2,3 . .10$, and then calculate the proportion of wage cuts as

$$
\operatorname{Pr} \text { opcut }=0.2 \gamma\left(D_{1}+D_{2}+D_{3}+D_{4}+D_{5}\right)+0.2(1-\gamma)\left(D_{6}+D_{7}+D_{8}+D_{9}+D_{10}\right)
$$




\section{References:}

Agell, J. og P. Lundborg (1999). Survey evidence on wage rigidity and unemployment. IFAU WP 1999:2, Uppsala, Sverige.

Akerlof, G.A., W.T. Dickens and W.L. Perry. (1996). The macroeconomics of low inflation. Brookings Papers on Economic Activity 1, 1-75.

Akerlof, G.A., W.T. Dickens and W.L. Perry. (2000). Near rational wage and price setting and the long run Phillips curve. Brookings Papers on Economic Activity 1, 1-60.

Altonji, J.G. and P.J. Devereux (1999). The extent and consequences of downward nominal wage rigidity. NBER Working Paper 7236.

Ball, L. and N. G. Mankiw (1994). Asymmetric price adjustment and economic fluctuations. Economic Journal, 247-261.

Beissinger, T. and C. Knoppik (2000). Downward nominal rigidity in West-German earnings 1975-1995. University of Regensburg Discussion Paper No 344.

Bewley, T.F. (1999). Why Wages Do Not Fall During a Recession? Harvard University Press.

Blanpain, R. (ed) (1994). International Encyclopaedia for Labour Law and Industrial Relations. Deventer: Kluwer Law and Taxation Publishers.

Binmore, K., A. Rubinstein, and A. Wolinsky (1986).The Nash bargaining solution in economic modelling. RAND Journal of Economics 17, 176-188.

Binmore, K., A.Shaked, and J. Sutton (1989). An outside option experiment. Quarterly Journal of Economics 104, 753-770.

Bullard, J. and J.W. Keating (1995). The long-run relationship between inflation and output in postwar economies. Journal of Monetary Economics 36, 477-496.

Calmfors, L. A Booth, M. Burda, D Checchi, R Naylor, and J. Visser (2001). The future of collective bargaining in Europe. In T. Boeri, A Brugiavini, and L. Calmfors (eds). The Role of Unions in the Twenty-First Century Oxford: Oxford University Press.

Christofides, L.N. and M.T. Leung (1999). Wage adjustment in contract data: Wage rigidity and menu costs. Mimeo, University of Guelph.

Cramton, P. and J. Tracy. (1992). Strikes and holdout in wage bargaining. Theory and data. American Economic Review 82, 100-121.

Dessy, O. (1999). Wage rigidity in Italy. University of Southampton working paper. 
Fehr, E. and L. Goette (2000). Robustness and real consequences of nominal wage rigidity. Institute for Empirical Research in Economics, University of Zurich, WP 44.

Feldstein, M. (1997). The Costs and Benefits of Going from Low Inflation to Price Stability. In C.D. Romer and D.H. Romer (eds). Reducing Inflation: Motivation and Strategy. The University of Chicago Press.

Fortin, P. and K. Dumont (2000). The shape of the long-run Phillips curve: Evidence from Canadian macrodata, 1956-97. Mimeo, Canadian Institute for Advanced Research.

Gordon, R. J (1996). Comment on Akerlof, Dickens and Perry, The macroeconomics of low inflation, Brookings Papers on Economic Activity 1, 61-66.

Gottfries, N. (1992). Insiders, outsiders, and nominal wage contracts. Journal of Political Economy 100, 252-270.

Holden, S. (1989). Wage drift and bargaining. Evidence from Norway. Economica 56, 419-432.

Holden, S. (1994). Wage bargaining and nominal rigidities, European Economic Review 38, 1994, 1021-1039.

Holden, S. (1997). Wage bargaining, holdout, and inflation. Oxford Economic Papers 49, 235-255.

Holden, S. (1999). Renegotiation and the efficiency of investment. Rand Journal of Economics 30, 106-119.

Holden, S. (2001). Does price stability exacerbate labour market rigidities in the EMU Empirica 28, 403-418.

Keynes, J.M. (1936). The General Theory of Employment, Interest and Money. MacMillan.

Kimura, T. and K. Ueda (1997). Downward nominal wage rigidity in Japan: Is price stability costly? Working Paper, Bank of Japan.

Kramarz, F. (2001).Rigid Wages: What Have we Learnt from Microeconometric Studies, in Advances in Macroeconomic Theory, J. Drèze ed., 194-216, Oxford University Press, Oxford, UK.

Knoppik, C. and T. Beissinger (2001). How rigid are nominal wages? Evidence and implications for Germany. IZA Discussion Paper 357, University of Regensburg.

Layard, R., S. Nickell and R. Jackman. (1991). Unemployment: Macroeconomic Performance and the Labour Market. Oxford University Press. 
Lebow, D.E, R.E. Saks, and B.A. Wilson (2000). Downward nominal wage rigidity. Evidence from the employment cost index. WP, Board of Governors of the Federal Reserve System.

Lundborg, P. and H. Sacklèn (2001). Is there a long run unemployment-inflation trade-off in Sweden?. FIEF working paper 173, Stockholm.

MacLeod, W.B. and J.M. Malcomson (1993). Investment, holdup, and the form of market contracts. American Economic Review 37, 343-354.

Malcomson, J.M. (1997). Contracts, hold-up, and labor markets. Journal of Economic Literature 35 (4), 1916-1957.

McDonald, I. (1995). Models of the range of equilibria. In R. Cross (ed). The Natural Rate of Unemployment: Reflections on 25 years of the hypothesis. Cambridge:

Cambridge University Press.

Moene, K.O. (1988). Union threats and wage determination. Economic Journal 98, 471483.

Nickell, S.J and Quintini (2001). Mimeo, Centre for Economic Performance, London. van Ours, J.C. and R.F. van de Wijngaert (1992). Holdouts and wage negotiations in the Netherlands, mimeo, Free University, Amsterdam.

Rubinstein, A. (1982). Perfect equilibrium in a bargaining model. Econometrica 50, 97109.

Shafir, E., P. Diamond and A. Tversky (1997). Money illusion. Quarterly Journal of Economics CXII, 341-374.

Shapiro, C. and J. Stiglitz (1984). Equilibrium unemployment as a worker discipline device. American Economic Review 74, 433-444.

Tobin, J. (1972). Inflation and unemployment. American Economic Review 62, 1-18.

Taylor, J. (1979). Staggered wage setting in a macro model. $\underline{\text { American Economic Review }}$ $\underline{69}, 108-113$. 
Figure 1. The wage bargaining

Negligible time

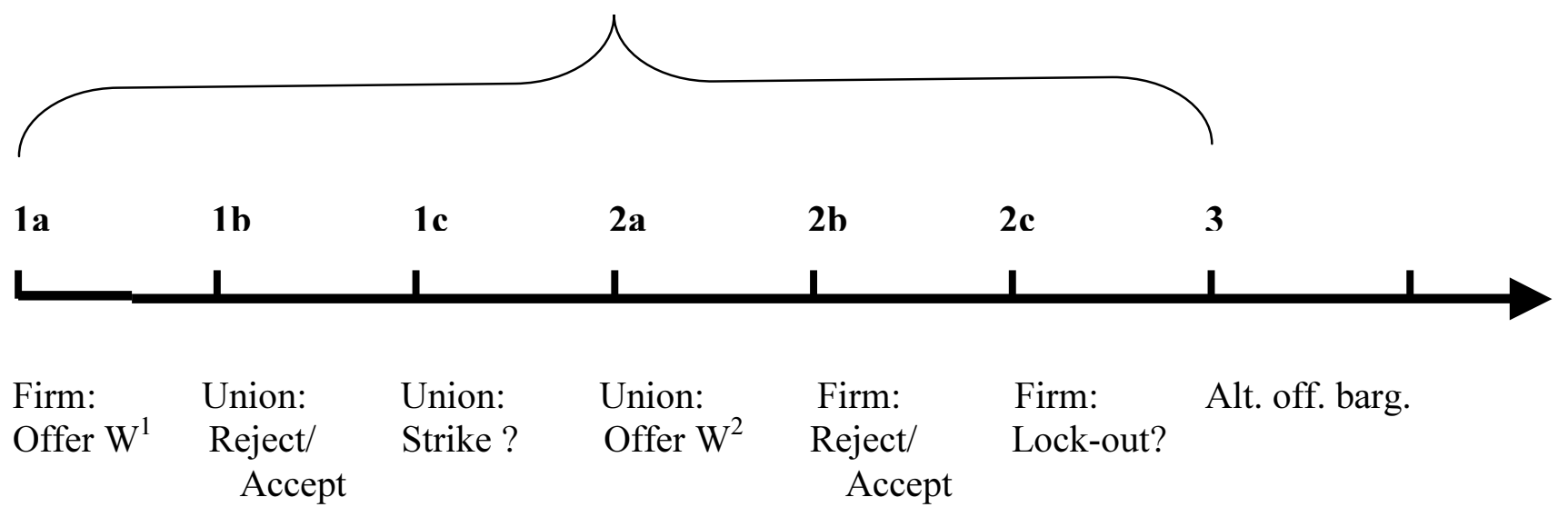

Figure 2 Simulation in Gauss. For parameter values, see basis case in Table 1.

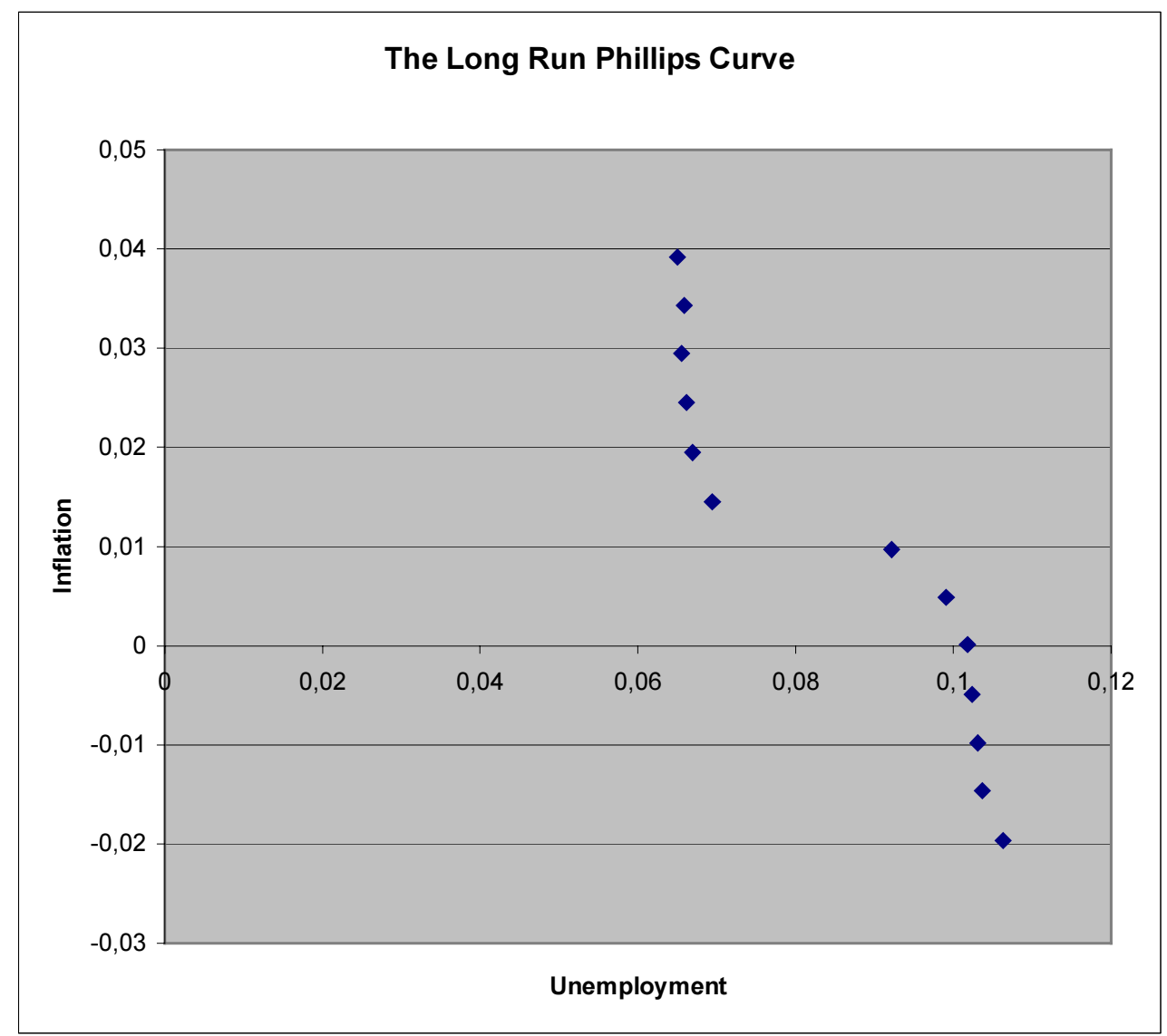


Table 1: Long run unemployment rates for different rates of inflation

\begin{tabular}{|r|r|r|r|r|r|r|r|r|}
\hline Inflation & Basis & $\gamma=0.50$ & $\gamma=0.25$ & $\begin{array}{l}\gamma=0.15 \\
\mathrm{z}=0.01\end{array}$ & $\lambda^{\mathrm{L}}=0.8$ & $\kappa^{\mathrm{U}}=0$ & $\alpha=0$ & \\
\hline-0.020 & 0.106 & 0.091 & 0.076 & 0.063 & 0.143 & 0.095 & 0.110 & 0.107 \\
\hline-0.015 & 0.104 & 0.086 & 0.069 & 0.061 & 0.141 & 0.069 & 0.109 & 0.104 \\
\hline-0.010 & 0.103 & 0.085 & 0.067 & 0.060 & 0.140 & 0.067 & 0.109 & 0.103 \\
\hline-0.005 & 0.102 & 0.084 & 0.066 & 0.059 & 0.140 & 0.066 & 0.109 & 0.102 \\
\hline 0.000 & 0.102 & 0.083 & 0.066 & 0.059 & 0.138 & 0.065 & 0.106 & 0.095 \\
\hline 0.005 & 0.099 & 0.083 & 0.065 & 0.058 & 0.137 & 0.065 & 0.104 & 0.093 \\
\hline 0.010 & 0.092 & 0.076 & 0.062 & 0.056 & 0.128 & 0.066 & 0.103 & 0.086 \\
\hline 0.014 & 0.069 & 0.062 & 0.055 & 0.052 & 0.077 & 0.066 & 0.102 & 0.078 \\
\hline 0.019 & 0.067 & 0.061 & 0.054 & 0.052 & 0.070 & 0.065 & 0.102 & 0.071 \\
\hline 0.025 & 0.066 & 0.060 & 0.054 & 0.051 & 0.067 & 0.065 & 0.100 & 0.069 \\
\hline 0.029 & 0.066 & 0.060 & 0.054 & 0.052 & 0.065 & 0.065 & 0.091 & 0.067 \\
\hline 0.034 & 0.066 & 0.060 & 0.054 & 0.051 & 0.066 & 0.065 & 0.069 & 0.067 \\
\hline 0.039 & 0.065 & 0.060 & 0.054 & 0.051 & 0.066 & 0.065 & 0.067 & 0.066 \\
\hline
\end{tabular}

The first column shows the rate of inflation, the other columns the associated rates of unemployment. Basis simulation: $\eta=3, \gamma=0.75, \lambda^{\mathrm{S}}=0.97, \lambda^{\mathrm{L}}=0.9$ (this implies that $\mathrm{k}^{\mathrm{S}}=$ 1.076 and $\left.\mathrm{k}^{\mathrm{L}}=1.137\right), \varphi=0.3,1 / v=0.68, \mathrm{~B}=0.3, \mathrm{k}^{\mathrm{E}}=1.05, \mathrm{z}=0.03, \kappa=0.03, \sigma=1.8$, productivity growth $\alpha=0.02$. The other columns show effect of deviation indicated in the top row. For $\lambda^{\mathrm{L}}=0.8$, we get $\mathrm{k}^{\mathrm{L}}=1.206$. The different inflation rates are generated by different exogenously chosen money growth rates, where the inflation rate is approximately the money growth rate minus productivity growth.

Table 2: Proportion of nominal wage cuts for different rates of inflation

\begin{tabular}{|r|r|r|r|r|r|r|r|r|}
\hline Inflation & Basis & $\gamma=0.50$ & $\gamma=0.25$ & $\begin{array}{l}\gamma=0.15 \\
\mathrm{z}=0.01\end{array}$ & $\lambda^{\mathrm{L}}=0.8$ & $\kappa^{\mathrm{U}}=0$ & $\alpha=0$ & \\
\hline-0.020 & 0.390 & 0.290 & 0.194 & 0.371 & 0.425 & 0.048 & 0.933 & 0.491 \\
\hline-0.015 & 0.270 & 0.178 & 0.095 & 0.210 & 0.271 & 0.003 & 0.875 & 0.283 \\
\hline-0.010 & 0.174 & 0.128 & 0.061 & 0.102 & 0.166 & 0.001 & 0.791 & 0.221 \\
\hline-0.005 & 0.072 & 0.056 & 0.024 & 0.033 & 0.084 & 0.000 & 0.600 & 0.180 \\
\hline 0.000 & 0.037 & 0.016 & 0.006 & 0.021 & 0.024 & 0.000 & 0.383 & 0.082 \\
\hline 0.005 & 0.000 & 0.000 & 0.002 & 0.001 & 0.003 & 0.000 & 0.261 & 0.046 \\
\hline 0.010 & 0.000 & 0.000 & 0.000 & 0.003 & 0.000 & 0.000 & 0.156 & 0.031 \\
\hline 0.014 & 0.000 & 0.000 & 0.000 & 0.000 & 0.000 & 0.000 & 0.090 & 0.004 \\
\hline 0.019 & 0.000 & 0.000 & 0.000 & 0.000 & 0.000 & 0.000 & 0.033 & 0.001 \\
\hline 0.025 & 0.000 & 0.000 & 0.000 & 0.000 & 0.000 & 0.000 & 0.012 & 0.001 \\
\hline 0.029 & 0.000 & 0.000 & 0.000 & 0.000 & 0.000 & 0.000 & 0.000 & 0.000 \\
\hline 0.034 & 0.000 & 0.000 & 0.000 & 0.000 & 0.000 & 0.000 & 0.000 & 0.000 \\
\hline 0.039 & 0.000 & 0.000 & 0.000 & 0.000 & 0.000 & 0.000 & 0.000 & 0.000 \\
\hline
\end{tabular}

See table 1 . 